\title{
Ethanol extract of paeonia suffruticosa Andrews (PSE) induced AGS human gastric cancer cell apoptosis via fas-dependent apoptosis and MDM2-p53 pathways
}

Hyeong Sim Choi ${ }^{1+}$, Hye-Sook Seo ${ }^{1+}$, Ji Hye Kim ${ }^{1}$, Jae-Young Um², Yong Cheol Shin ${ }^{1}$ and Seong-Gyu Ko ${ }^{1,2,3^{*}}$

\begin{abstract}
Background: The root bark of Paeonia suffruticosa Andrews (PSE), also known as Moutan Cortex, has been widely used in Asia to treat various diseases. The molecular mechanisms by which PSE exerts its anti-oxidant and antiinflammatory activities are well known, but its anti-cancer activity is not yet well understood. Here, we present evidence demonstrating that PSE can be used as a potent anti-cancer agent to treat gastric cancer.

Methods: The effects of the ethanol extract of PSE on cell proliferation were determined using an MTT (1-(4,5dimethylthiazol-2-yl)-3,5-diphenylformazan) assay. Cell cytotoxicity induced by the PSE extact is measured using an LDH leakage assay. Flow cytometry was used to analyze the cell cycle and to measure the subG0/G1 apoptotic cell fraction. Apoptosis induced by the PSE extact is also examined using a DNA fragmentation assay. Western blot analysis is used to measure the levels of apoptotic proteins such as Fas receptor, caspase-8, caspase-3, PARP, Bax, BCl-2, MDM2, and p53.

Results: This study demonstrated that treating AGS cells with the PSE extact significantly inhibited cell proliferation and induced cytotoxicity in a dose- and time-dependent manner. The PSE extract also induced apoptosis in AGS cells, as measured by flow cytometry and a DNA fragmentation assay. We found that the PSE extract induced apoptosis via the extrinsic Fas-mediated apoptosis pathway, which was concurrent with the activation of caspases, including caspase-8 and caspase-3, and cleavage of PARP. The MDM2-p53 pathway also played a role in the apoptosis of AGS cells that was induced by the PSE extract.
\end{abstract}

Conclusions: These results clearly demonstrate that the PSE extact displays growth-suppressive activity and induces apoptosis in AGS cells. Our data suggest that the PSE extact might be a potential anti-cancer agent for gastric cancer.

Keywords: Paeonia suffruticosa Andrews, Fas, MDM2, p53, Gastric cancer

\footnotetext{
* Correspondence: epiko@khu.ac.kr

†Equal contributors

'Laboratory of Clinical Biology and Pharmacogenomics and Center for

Clinical Research and Genomics, Institute of Oriental Medicine, Kyung Hee University

${ }^{2}$ Department of Pharmacology, Institute of Oriental Medicine, Kyung Hee University

${ }^{3}$ Laboratory of Clinical Biology and Pharmacogenomics, Department of Basic Science of Oriental Medicine, College of Oriental Medicine, Kyung Hee

University 1 Hoegi-dong, Dongdaemun-gu, Seoul 130-701, Republic of Korea
} 


\section{Background}

Apoptosis, or programmed cell death, occurs under physiological and pharmacological stress in eukaryotic cells [1-4]. The hallmarks of apoptotic cell death include cell shrinkage, membrane blebbing, nuclear fragmentation, and chromatin condensation. These apoptotic changes are due to the proteolytic activity of the caspase proteases [5-7]. Apoptosis is mediated by either extrinsic or intrinsic pathways, and both pathways converge on the activation of effector caspases by initiator caspases. In the extrinsic apoptosis pathway, Fas (also called Apo1 or CD95) is activated when the cell-surface death receptors are upregulated, and activated Fas can then activate the initiator caspases. The effector caspases are directly cleaved and activated by initiator caspases, resulting in the cleavage, degradation, or activation of other cellular proteins. In the intrinsic apoptosis pathway, mitochondrial outer membrane permeabilization (MOMP) is changed, and the B cell lymphoma 2 (Bcl-2) family plays a central role in cell death regulation. This process leads to the release of pro-apoptotic proteins from the mitochondrial intermembrane space (IMS) [5].

Worldwide, gastric cancer is the second leading cause of cancer-related deaths, with only lung cancer ranking higher $[8,9]$. The incidence of gastric cancer is high in Eastern Asia, including Korea and Japan, as well as in Eastern Europe, and South America. In contrast, the incidence of gastric cancer is low in North America, Oceania, Northern Europe, Southeast Asia, and Southern Asia [10]. A course of chemotherapy has been shown to be effective in treating gastric cancer, but therapy-associated side effects have also been reported [11]. Although various advances have arisen in gastric cancer management, patient prognosis remains very poor [12]. Therefore, it is essential to find new agents that can be used to enhance the anti-cancer effects of common chemotherapeutic drugs currently being used for gastric cancer treatment $[11,12]$.

Although traditional medicine has been used for thousands of years [13], the molecular mechanisms underlying the effects of these natural products obtained from the extracts of medicinal plants is still unclear [14-16]. Identification of the biologically active compound is also important in traditional medicine [17].

Moutan Cortex, the root bark of Paeonia suffruticosa Andrews (PSE), belongs to the Paeoniaceae family [18]. PSE has been widely used in Asia to treat atherosclerosis, infection, inflammation, and cutaneous disease [19]. PSE has been shown to possess potent anti-oxidant, anti-mutagenic, anti-proliferative, anti-invasive [20], anti-arrhythmic [21], anti-inflammation [22], antidiabetic [23,24], and anti-obesity activities [25]. However, the molecular mechanisms by which PSE exerts its anticancer activity are not well understood. In the present study, we investigated whether PSE displays growth suppressive activity and induces apoptosis in AGS cells. Here, we provide evidence that PSE can be used as a potent anti-cancer agent to treat gastric cancer.

\section{Methods \\ Reagents}

RPMI 1640, FBS (fetal bovine serum), trypsin-EDTA, and Dulbecco's phosphate-buffered saline (D-PBS) were purchased from Welgene (Daegu, Korea). The antibioticantimycotic used was purchased from Gibco (Grand Island, NY, USA). MTT (1-(4,5-dimethylthiazol-2-yl)-3,5diphenylformazan; Thiazolyl blue formazan), RNase A, chloroform, potassium acetate, and p53 inhibitor (Pifithrin- $\alpha$ ) were purchased from Sigma-Aldrich (St. Louis, MO, USA). An LDH leakage (CytoTox $96^{\circledR}$ NonRadioactive Cytotoxicity) assay kit was purchased from Promega (Madison, WI, USA). The pan-caspase inhibitor (z-VAD-fmk) was obtained from Calbiochem-Novabiochem (La Jolla, CA, USA). Caspase-8 inhibitor (Z-IETD-fmk) and caspase-9 inhibitor (Z-LEHD-fmk) were obtained from R\&D systems, Inc (Minneapolis, MN, USA). An EZwestern chemiluminescent detection kit was purchased from Daeillab service co. (Seoul, Korea). Cisplatin was obtained from Ildong Pharmaceutical Co., Ltd (Seoul, Korea).

\section{Antibodies}

Fas receptor, procaspase- 3 , cleaved caspases $(-3$ and -8$)$, and poly (ADP-ribose) polymerase (PARP) antibodies were purchased from Cell Signaling Technology, Inc (Danvers, MA, USA). Pro- and cleaved caspase-9, Bcl-2, Bax and $\alpha$-actin antibodies were purchased from Santa Cruz Biotechnology (Santa Cruz, CA, USA). Mouse and rabbit secondary antibodies were from CalbiochemNovabiochem (La Jolla, CA, USA). Goat secondary antibody was obtained from Jackson ImmunoResearch (West Grove, PA, USA).

\section{Preparation of Paeonia suffruticosa Andrews (PSE) extract}

The bark of roots obtained from Paeonia suffruticosa Andrews (PSE) used in this research was purchased from Omniherb (Gyeong Buk, Korea). The roots of PSE (100 g) were immersed twice in $1 \mathrm{~L}$ of $80 \%$ ethanol and then sonicated using an ultra-sonicator (Branson, USA) for $30 \mathrm{~min}$ at room temperature. The resulting extract was then filtered through a $0.22 \mathrm{~mm}$ filter and concentrated to approximately $100 \mathrm{~mL}$ under reducing pressure. The ethanol extracts were dried in a $42^{\circ} \mathrm{C}$ water bath with the use of a vacuum pump evaporator (Eyela, Japan) and then freezedried for $72 \mathrm{~h}$ by freeze dryer (Matsushita, Japan). The concentrated extract was then lyophilized, resulting in $20.5 \mathrm{~g}$ of powder that was subsequently dissolved in DMSO to prepare a stock solution of $200 \mathrm{mg} / \mathrm{mL}$. The stock solution was stored at $-80^{\circ} \mathrm{C}$ until use. 


\section{Cell culture}

AGS (human gastric cancer) cells were generously provided by Dr. H. P. Kim (Seoul National Cancer Institute, Seoul, Korea) and maintained as a monolayer culture in RPMI 1640 medium that was supplemented with $10 \%$ FBS and $1 \%$ antibiotic-antimycotic at $37^{\circ} \mathrm{C}$ in a humidified incubator under $5 \% \mathrm{CO}_{2}$ gas.

\section{MTT assay}

Inhibition of cell proliferation was determined using a MTT assay. Briefly, AGS cells were seeded in a 96 multiwell plate $\left(5 \times 10^{3}\right.$ cells $\left./ 100 \mu \mathrm{l}\right)$, and incubated at $37^{\circ} \mathrm{C}$. The next day, the cells were treated with the PSE extract $(0,0.01,0.05,0.1,0.25$ and $0.5 \mathrm{mg} / \mathrm{ml})$ for 48 or $72 \mathrm{~h}$. After incubation, MTT reagents $(0.5 \mathrm{mg} / \mathrm{ml})$ were added to each well, and the plates were incubated in the dark at $37^{\circ} \mathrm{C}$ for $2 \mathrm{~h}$. The medium was removed, formazan was dissolved in DMSO, and the optical density was measured at $570 \mathrm{~nm}$ using an ELISA plate reader. The absorbance correlates with the viability of cells; therefore, the number of cells (\% of control) was calculated using the following formula: cell number (\% of control) = ((absorbance of cells treated with herb extract) / (absorbance of control cells) $) \times 100$. The control was AGS cells without herb extract treatment.

\section{LDH leakage assay}

Cell cytotoxicity was determined by a LDH leakage assay. Briefly, AGS cells were seeded in a 24 multi-well plate $\left(1.5 \times 10^{4}\right.$ cells $\left./ \mathrm{ml}\right)$, and incubated at $37^{\circ} \mathrm{C}$. The next day, the cells were treated with the PSE extract $(0$, $0.01,0.05,0.1,0.25$ and $0.5 \mathrm{mg} / \mathrm{ml}$ ) for 48 or $72 \mathrm{~h}$. After incubation, the supernatant was transferred to EP tubes and then centrifuged at $11,000 \mathrm{rpm}$ for $5 \mathrm{~min}$ at $4^{\circ} \mathrm{C}$.
The supernatant was then transferred to new EP tubes. Next, $50 \mu$ l of the supernatant was pipetted into 96 multi-well plates, and the supernatant was mixed with $50 \mu \mathrm{l}$ of CytoTox $96^{\circledR}$ Non-Radioactive Cytotoxicity assay reagents. After $30 \mathrm{~min}$ of incubation in the dark at room temperature, $50 \mu \mathrm{l}$ of stop solution was added to each well. The absorption values were measured at $492 \mathrm{~nm}$ using an ELISA plate reader. The absorbance correlates to the viability of cells; therefore, the number of cells (\% of control) was calculated using the following formula: cell number ( $\%$ of control $)=($ absorbance of cells treated with herb extract) / (absorbance of control cells) $\times 100$. The control was AGS cells without herb extract treatment.

\section{Cell proliferation assay}

Cells were seeded in 12-well culture plates at a density of $5 \times 10^{4}$ cells/well. The next day, cells were treated with caspase- 8 inhibitor or caspase- 9 inhibitor in the presence or absence of PSE for 3 days. Cells were harvested by trypsinization, resuspended in 1-2 $\mathrm{ml}$ of medium, and counted using a hemocytometer.

\section{Cell cycle or DNA content analysis by flow cytometry}

Cells were seeded in $60 \mathrm{~mm}$ dishes $\left(2.5 \times 10^{5}\right.$ cells $\left./ 3 \mathrm{ml}\right)$ and incubated at $37^{\circ} \mathrm{C}$. The next day, $200 \mu \mathrm{g} / \mathrm{ml}$ of PSE was directly added to the culture media and incubated for an additional 12, 24, or $36 \mathrm{~h}$. After incubation, the cells were washed with ice-cold PBS, trypsinized, collected in a $15 \mathrm{ml}$ conical tube, and pelleted by centrifugation $(1000 \mathrm{xg})$ for $5 \mathrm{~min}$ at $4^{\circ} \mathrm{C}$. The pellets were washed twice with ice-cold PBS, fixed in $70 \%$ ethanol, washed in PBS, resuspended in $300 \mu \mathrm{l}$ of PBS containing $50 \mu \mathrm{g} / \mathrm{ml}$ propidium iodide (PI) and $50 \mu \mathrm{g} / \mathrm{ml}$ RNase A

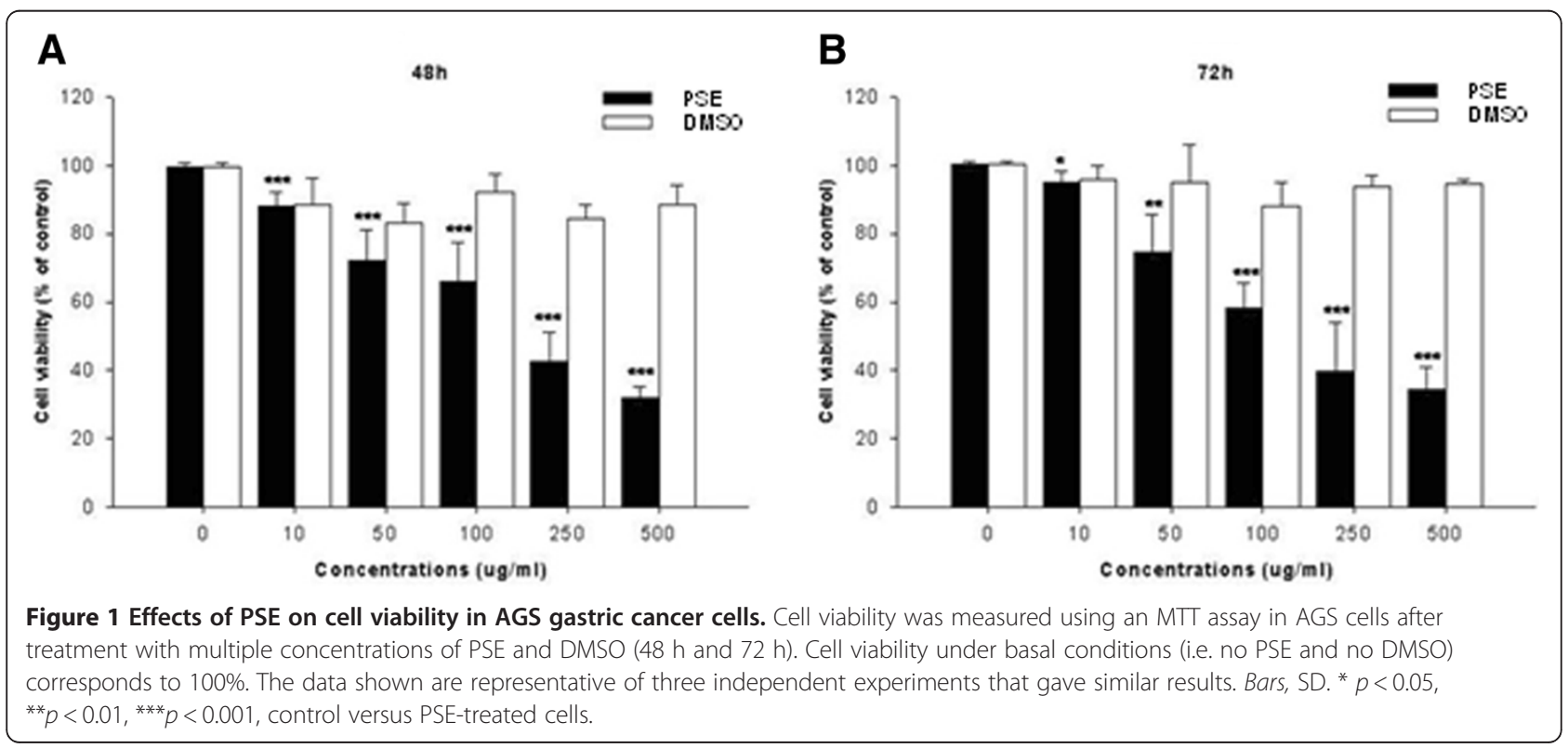


(Sigma), and incubated in the dark for $15 \mathrm{~min}$ at room temperature. The DNA content in each cell nucleus was determined with a FACSCalibur flow cytometer (BectonDickinson, San Jose, CA, USA), and the cell cycle was analyzed using ModFit LT V2.0 software.

\section{DNA fragmentation assay}

Cells $\left(6 \times 10^{5}\right.$ cells $\left./ 6 \mathrm{ml}\right)$ were lysed in $500 \mu \mathrm{l}$ of $0.3 \mathrm{M}$ Tris- $\mathrm{HCl}$ (pH 7.5) buffer containing $0.1 \mathrm{M} \mathrm{NaCl}$, $0.01 \mathrm{M}$ EDTA, and $0.2 \mathrm{M}$ sucrose. After vortexing briefly, $25 \mu \mathrm{l}$ of $10 \%$ SDS was added to the samples, and the samples were incubated for $30 \mathrm{~min}$ at $37^{\circ} \mathrm{C}$. Next, $120 \mu \mathrm{l}$ of $5 \mathrm{M} \mathrm{KOAC}$ (potassium acetate) was added to the samples, and the samples were kept on ice for $1 \mathrm{~h}$. After centrifugation for $10 \mathrm{~min}$ at $4{ }^{\circ} \mathrm{C}$ (at $15,000 \mathrm{rpm}$ for pellet formation), the pellets were removed. The supernatant was treated with $500 \mu \mathrm{l}$ of TE buffer $(10 \mathrm{mM}$ Tris- $\mathrm{HCl}$ and $1 \mathrm{mM}$ EDTA, pH 8.0) containing $2 \mu \mathrm{l}$ of RNase A $(10 \mathrm{mg} / \mathrm{ml})$ and was incubated for $30 \mathrm{~min}$ at room temperature. An equal volume of phenol/chloroform/isoamyl alcohol (25/24/1; Usb) was added to the supernatant. The supernatant was vortexed gently and centrifuged for $30 \mathrm{~min}$ at $4^{\circ} \mathrm{C}$ (at $15,000 \mathrm{rpm}$ ). The supernatant was removed and $400 \mu \mathrm{l}$ of $100 \% \mathrm{EtOH}$ and $80 \mu \mathrm{l}$ of $3 \mathrm{M} \mathrm{NaOAC}$ were added to the pellets. The pellets were mixed gently and incubated at $-20^{\circ} \mathrm{C}$ for $30 \mathrm{~min}$. After centrifugation for $30 \mathrm{~min}$ at $4^{\circ} \mathrm{C}$ (at $15,000 \mathrm{rpm}$ ), the supernatants were removed. Next, the pellets were washed twice with $500 \mu \mathrm{l}$ of $70 \% \mathrm{EtOH}$ and were centrifuged for $30 \mathrm{~min}$ at $4^{\circ} \mathrm{C}$ (at $15,000 \mathrm{rpm}$ ). After removal of the supernatant, the pellets were dried and dissolved in $10 \mu \mathrm{l}$ of TE buffer. The DNA was loaded on a $1.2 \%$ agarose gel.

\section{Western blot analysis}

Harvested cells were lysed with buffer containing $20 \mathrm{mM}$ Tris- $\mathrm{HCl}$ (pH 7.5), $150 \mathrm{mM} \mathrm{NaCl}, 1 \mathrm{mM}$ EDTA, $1 \mathrm{mM} \mathrm{Na}{ }_{2}$ EDTA, 1 mM EGTA, 1\% NP-40, 1\% sodium deoxycholate, $1 \mathrm{mM} \mathrm{Na} \mathrm{VO}_{4}, 1 \mathrm{mM}$ DTT, $1 \mathrm{mM} \mathrm{NaF}$, $1 \mathrm{mM}$ PMSF, and PI cocktail on ice for $30 \mathrm{~min}$. The lysates were cleared by centrifugation at $13,000 \mathrm{rpm}$ for $20 \mathrm{~min}$ at $4^{\circ} \mathrm{C}$. The supernatant was stored at $-70^{\circ} \mathrm{C}$ until use. The protein concentration was quantified using a Bio-Rad Bradford protein assay (Bio-Rad, Hercules, CA, USA). Next, total proteins $(15-20 \mu \mathrm{g})$ were electrophoresed using 6-15\% reducing SDSpolyacrylamide gels and transferred to nitrocellulose membranes. After blocking with $0.1 \%$ Tween-20 in PBS (PBST) containing 1\% skim milk and 1\% BSA for $1 \mathrm{~h}$, the membranes were incubated overnight at $4^{\circ} \mathrm{C}$ with the indicated primary antibodies. After washing in $1 \mathrm{X}$ PBST for $15 \mathrm{~min}$ (3 times $\mathrm{x} 5 \mathrm{~min}$ ), the membranes were incubated with diluted enzyme-linked secondary antibodies. After washing in $1 \mathrm{X}$ PBST for $1 \mathrm{~h}$ (4 times $\mathrm{x}$ $15 \mathrm{~min}$ ), the protein bands were detected using the EZwestern chemiluminescent detection kit and visualized by exposing the membranes to X-ray films. For the studies of caspase-dependent apoptosis, AGS cells were pretreated with $\mathrm{z}$-VAD-fmk $(50 \mu \mathrm{M})$ for $1 \mathrm{~h}$ before treatment with PSE.

\section{Statistical analysis}

All experiments were expressed as the means \pm standard deviations (SD) of at least three separate tests. Student's $t$-test was used for single variable comparisons, and a $p$ value $<0.05$ was considered statistically significant.
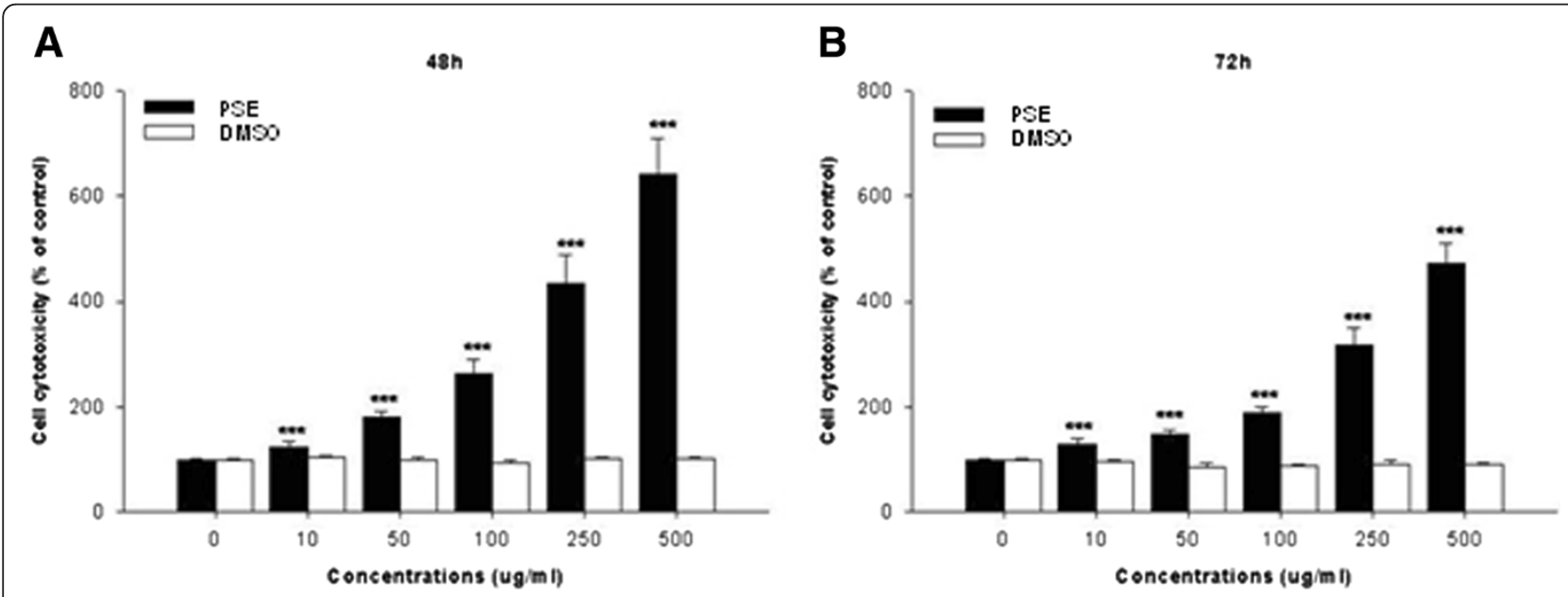

Figure 2 Effects of PSE on cell cytotoxicity in AGS gastric cancer cells. Cell cytotoxicity was measured by a LDH leakage assay in AGS cells after treatment with multiple concentrations of PSE and DMSO (48 h and $72 \mathrm{~h}$ ). Cell cytotoxicity under basal conditions (i.e. no PSE and no DMSO) corresponds to $100 \%$. The data shown are representative of three independent experiments that gave similar results. Bars, SD. ${ }^{* * *} p<0.001$, control versus PSE-treated cells. 


\section{Results}

The PSE extract inhibits cell proliferation in AGS cells

To investigate whether the PSE extract inhibits AGS cell growth, the cells were treated with various concentrations $(0-500 \mu \mathrm{g} / \mathrm{ml})$ of the PSE extract for 48 and $72 \mathrm{~h}$, and the viability was measured by a MTT assay. Interestingly, the PSE extract inhibited cell growth in both a dose- and a time-dependent manner (Figure 1). Compared with the control cells, the $\mathrm{IC}_{50}$ values of the PSE extract were approximately 220 and $200 \mu \mathrm{g} /$ $\mathrm{ml}$ at 48 and $72 \mathrm{~h}$, respectively. These data suggest that the PSE extract has a clear anti-proliferative effect on AGS cells.
The PSE extract induces cell cytotoxicity in AGS cells

To examine the potential cell cytotoxic effects of the PSE extract in AGS cells, the cells were treated with various concentrations $(0-500 \mu \mathrm{g} / \mathrm{ml})$ of the PSE extract for 48 and $72 \mathrm{~h}$, and the cytotoxicity was measured using CytoTox $96{ }^{\circledR}$ Non-Radioactive Cytotoxicity assay reagents. We found that PSE killed cells in both a dose- and a timedependent manner (Figure 2). Compared with the control cells, the $\mathrm{LC}_{50}$ values of the PSE extract were approximately 140 and $190 \mu \mathrm{g} / \mathrm{ml}$ at 48 and $72 \mathrm{~h}$, respectively. These results strongly suggest that the anti-proliferative effect of the PSE extract is caused by apoptotic cell death because the PSE extract killed the AGS cells.

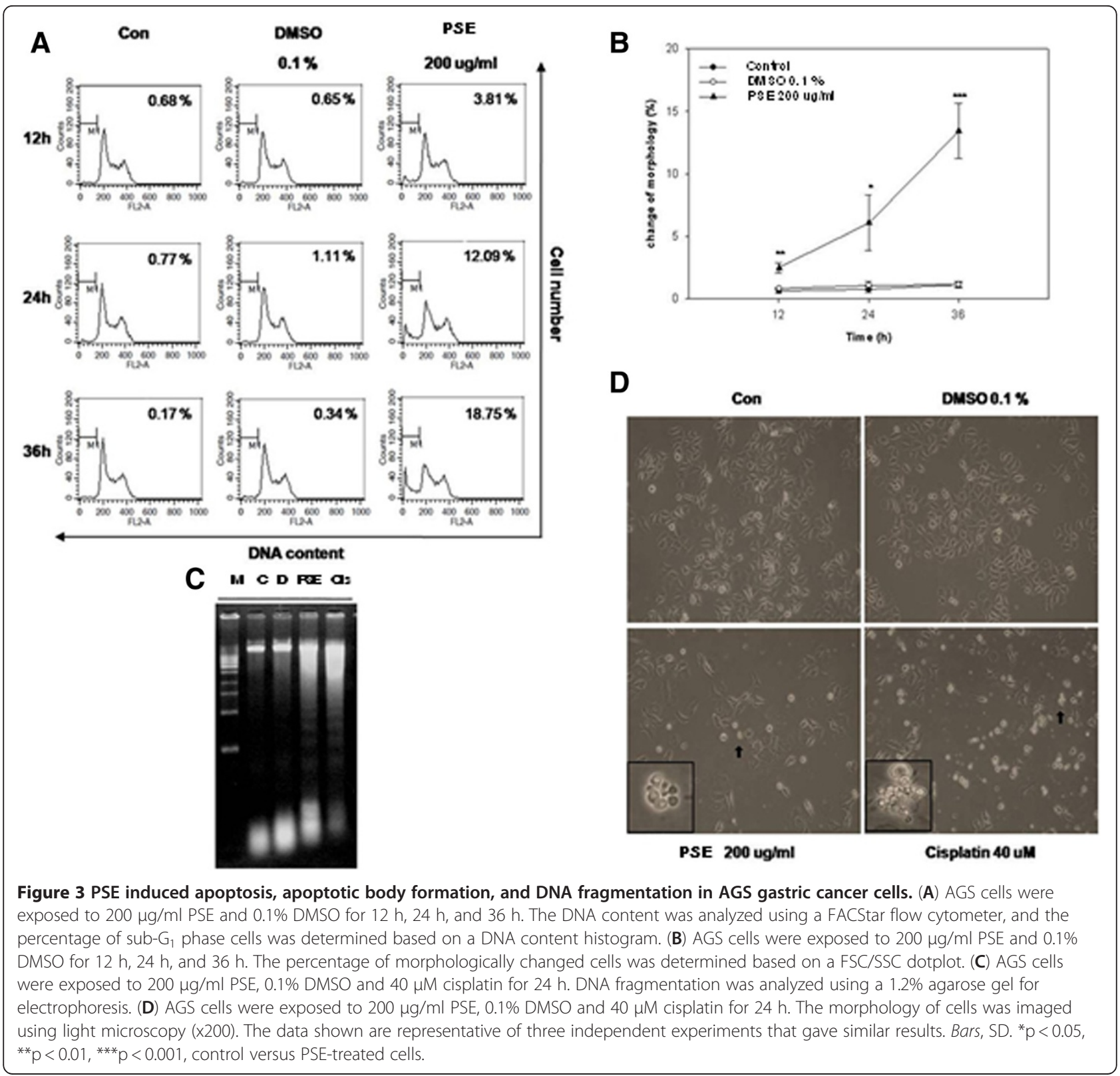


The PSE extract induces apoptosis, apoptotic body formation, and DNA fragmentation in AGS cells

To further study the cytotoxic effects of the PSE extract in AGS cells, we treated cells with $200 \mu \mathrm{g} / \mathrm{ml}$ of the PSE extract for $12-36 \mathrm{~h}$ and then analyzed the cells for sub$\mathrm{G}_{1}$ DNA contents using flow cytometry. At this concentration, the PSE extract increased the sub- $\mathrm{G}_{1}$ apoptotic fractions from $3.81 \%(12 \mathrm{~h})$ to $18.75 \%(36 \mathrm{~h})$ in a timedependent manner. In contrast, neither the untreated control cells nor the DMSO treated cells showed any significant changes in the sub- $\mathrm{G}_{1}$ apoptotic fraction (from $0.68 \%(12 \mathrm{~h}$ ) to $0.17 \%(36 \mathrm{~h})$ and from $0.65 \%$ $(12 \mathrm{~h})$ to $0.34 \%(36 \mathrm{~h})$, respectively) (Figure $3 \mathrm{~A})$.
Morphological analysis demonstrated that AGS cells were divided into either a distinct subpopulation (FSC < 150 ) or the main population of cells (FSC 150-440) after treatment with the PSE extract (Figure 3B). There was a time-dependent increase in the $\mathrm{FSC}<150$ population, from $2.47 \%(12 \mathrm{~h})$ to $13.42 \%(36 \mathrm{~h})$, after treatment with $200 \mu \mathrm{g} / \mathrm{ml}$ of the PSE extract. In contrast, we did not observe any statistically significant changes in control cells and DMSO treated cells.

A DNA fragmentation ladder showed that the PSE extract and cisplatin (positive control) induced apoptotic DNA ladder formation (Figure $3 \mathrm{C}$ ). Furthermore, the PSE extract decreased monolayer cell growth and

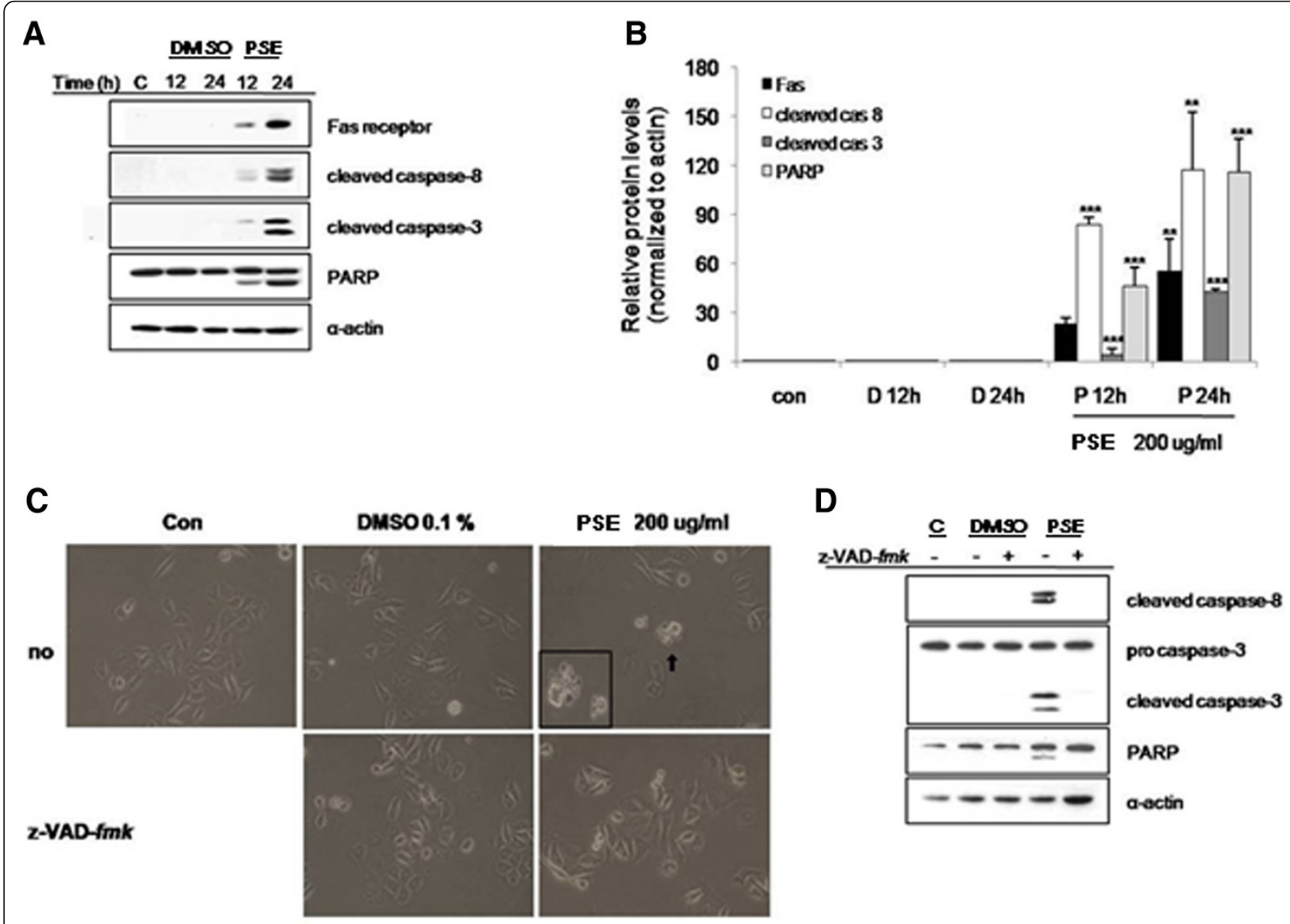

Figure 4 Fas, caspase-8 and caspase-3-dependent apoptosis is induced by PSE in AGS gastric cancer cells. (A) AGS cells were exposed to $200 \mathrm{\mu g} / \mathrm{ml}$ PSE and $0.1 \%$ DMSO for $12 \mathrm{~h}$ and $24 \mathrm{~h}$. The cell lysates were separated by SDS-PAGE gel electrophoresis, and Western blotting with specific antibodies was performed (anti-Fas receptor, anti-cleaved caspase-8, anti-cleaved caspase-3, anti-cleaved-PARP, and anti-a-actin). (B) The band intensities were normalized to a-actin. (C) AGS cells were exposed to $200 \mu \mathrm{g} / \mathrm{ml}$ PSE and $0.1 \%$ DMSO either with or without z-VAD-fmk (50 $\square$ M). The morphology of the cells was imaged using light microscopy (x200). (D) AGS cells were exposed to $200 \mathrm{\mu g} / \mathrm{ml}$ PSE and $0.1 \%$ DMSO

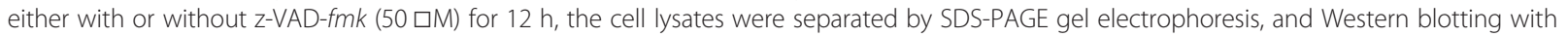
specific antibodies was performed (anti-procaspase-3, anti-cleaved caspase-8, anti-cleaved caspase-3, anti-cleaved-PARP, and anti-a-actin). The data shown are representative of three independent experiments that gave similar results. Bars, SD. ${ }^{* *} p<0.01,{ }^{* * *} p<0.001$, control versus PSEtreated cells. 
changed cellular morphology (Figure 3D). Cisplatin also showed similar cellular changes. These results confirmed that the PSE extract inhibits the proliferation of AGS cells by inducing apoptosis.

The PSE extract induces apoptosis via the extrinsic Fas-, caspase-8-, and caspase-3-dependent apoptosis pathway in AGS gastric cancer cells

We investigated whether the PSE extract induces the extrinsic apoptosis pathway in AGS cells. To address this question, we measured the expression of death receptor signaling-related proteins including Fas, caspase-8, caspase-3, and PARP. We found that the PSE extract activated the Fas death receptor and cleaved caspase-8, caspase-3, and PARP, as seen in Figure 4A and 4B. When we used z-VAD-fmk (pan-caspase inhibitor), we found that the growth inhibition induced by the PSE extract was abrogated (Figure 4C). Moreover, the cleavages of caspase- 8 , caspase- 3 , and PARP were inhibited by $\mathrm{z}$ VAD-fmk, while the PSE extract alone still led to the degradation of caspase-8, caspase-3, and PARP (Figure 4D).Collectively, these results suggest that the apoptotic cell death that is induced by the PSE extract in AGS cells occurs via the caspase-dependent extrinsic apoptosis pathway.

The PSE extract does not induce apoptosis through the intrinsic mitochondrial apoptosis pathway in AGS cells Next, we conducted an experiment to determine whether the PSE extract induces the intrinsic mitochondrial apoptosis pathway in AGS cells. We measured the expression of mitochondrial apoptosis pathway-related proteins such as the anti-apoptotic protein $\mathrm{Bcl}-2$ and the pro-apoptotic protein Bax. As seen in Figure $5 \mathrm{~A}$ and $5 \mathrm{~B}$, the expression of Bcl-2 and Bax was not changed by the PSE extract. Moreover, the mitochondrial apoptosis
A

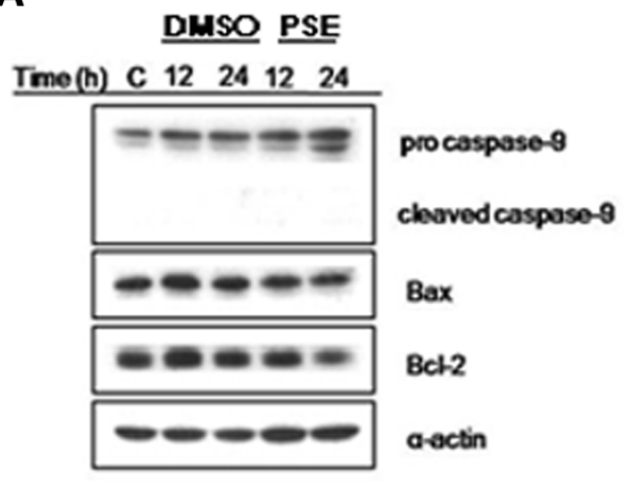

B

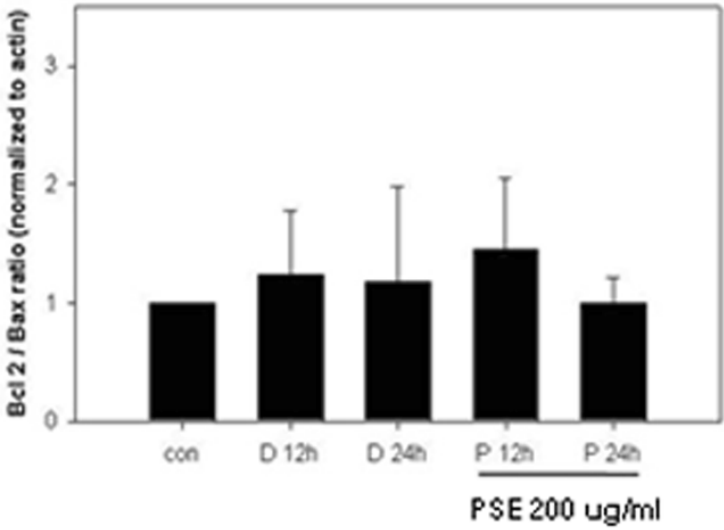

C

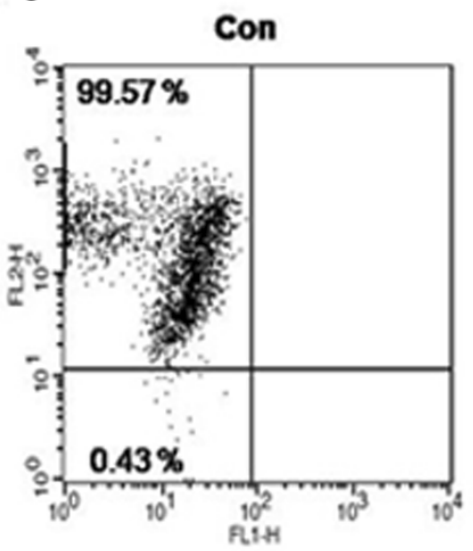

Daso $0.1 \%$

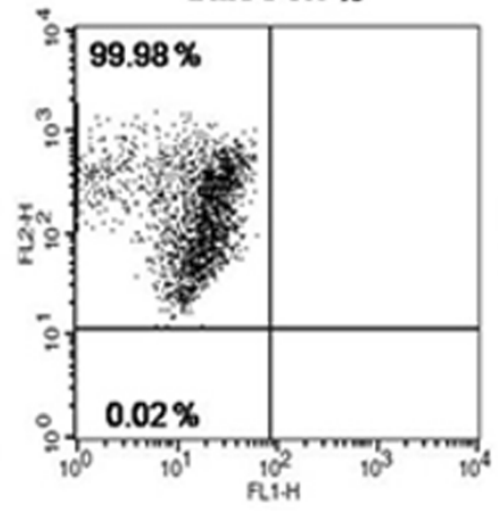

PSE $200 \mathrm{ug} / \mathrm{ml}$

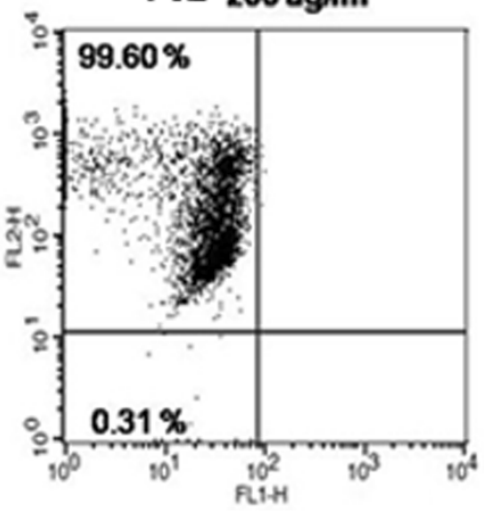

Figure 5 PSE does not induce the intrinsic apoptosis pathway in AGS gastric cancer cells. (A) AGS cells were exposed to $200 \mu \mathrm{m} / \mathrm{ml}$ PSE and $0.1 \%$ DMSO for $12 \mathrm{~h}$ and $24 \mathrm{~h}$. The cell lysates were separated by SDS-PAGE gel electrophoresis and Western blotting with specific antibodies was performed (anti-procaspase-9, anti-cleaved caspase-9, anti-cleaved-Bax, anti-cleaved-Bcl-2, and anti-a-actin). (B) The quantification of the Bcl2/Bax ratio of the band density was performed. (C) AGS cells were treated with $200 \mu \mathrm{g} / \mathrm{ml}$ PSE and $0.1 \%$ DMSO for 24 h, washed twice with PBS and stained with $4 \mathrm{\mu g} / \mathrm{ml} \mathrm{JC}-1$. The data shown are representative of three independent experiments that gave similar results. 
pathway-related caspase, caspase- 9 , was not cleaved by the PSE extract (Figure 5A).

To confirm the western blot data, we measured the loss of mitochondrial membrane potential $(\Delta \Psi \mathrm{m})$ using JC-1. JC-1 shows a high mitochondrial $\Delta \Psi \mathrm{m}$ with intense red fluorescence, forming J-aggregates when the cells are in a healthy non-apoptotic state. In apoptotic or unhealthy cells (especially mitochondria-mediated apoptotic cells), JC-1 shows green fluorescence, forming J-monomers that have a low $\Delta \Psi \mathrm{m}$. The data in Figure $5 \mathrm{C}$ demonstrate that the PSE extract did not affect mitochondria membrane potential, as seen by the maintenance of red fluorescence from $100 \%$ (control) to $100 \%$ (DMSO $0.1 \%$ ) to $99.91 \%$ (PSE). We suggest that the PSE extract does not induce intrinsic mitochondrial apoptosis in AGS cells but induce extrinsic death receptor related apoptosis.

To confirm whether the apoptosis induced by the PSE extract is only via extrinsic Fas-, caspase-8-, and caspase-3- dependent pathway, we treated AGS cells with caspase-8 inhibitor (Z-IETD-fmk) and caspase-9 inhibitor (Z-LEHD-fmk) and performed proliferation assay and western blot. We found that caspase-9 inhibitor alone decreased weakly cell proliferation suggesting that caspase-9 is not key enzyme to induce apoptosis (Figure 6A). We also found that the PSE extract strongly suppressed the cell proliferation even in the presence of caspase-8 inhibitor and caspase-9 inhibitor (Figure 6A). Western blot data demonstrated that cleavages of caspase- 8 , caspase-3, and PARP were inhibited by caspase- 8 inhibitor and caspase-9 inhibitor (Figure 6B). These results confirm that the apoptotic cell death that is induced by the PSE extract in AGS cells occurs via the caspase-dependent extrinsic apoptosis pathway.

\section{p53-dependent apoptosis is induced by the PSE extract in AGS cells}

We investigated whether the $\mathrm{p} 53$ protein, which plays an important role in the induction of apoptosis, is regulated by the PSE extract in AGS cells. We found that the PSE extract significantly increased the expression of the active form of p53 (phospho-p53), as seen in Figure 7A and $7 \mathrm{~B}$. Interestingly, the expression of the active form of MDM2 (phospho-MDM2), a negative regulator of p53, was decreased. To confirm that p53 is implicated in the apoptosis induced by the PSE extract, we treated AGS cells with p53 inhibitor (Pifithrin- $\alpha$ ) and performed western blot. We found that cleavages of caspase-8, caspase-3, and PARP were inhibited by p53 inhibitor (Figure 7C). These data suggest that the PSE extract induces apoptosis via the MDM2-p53-dependent pathway in AGS cells.

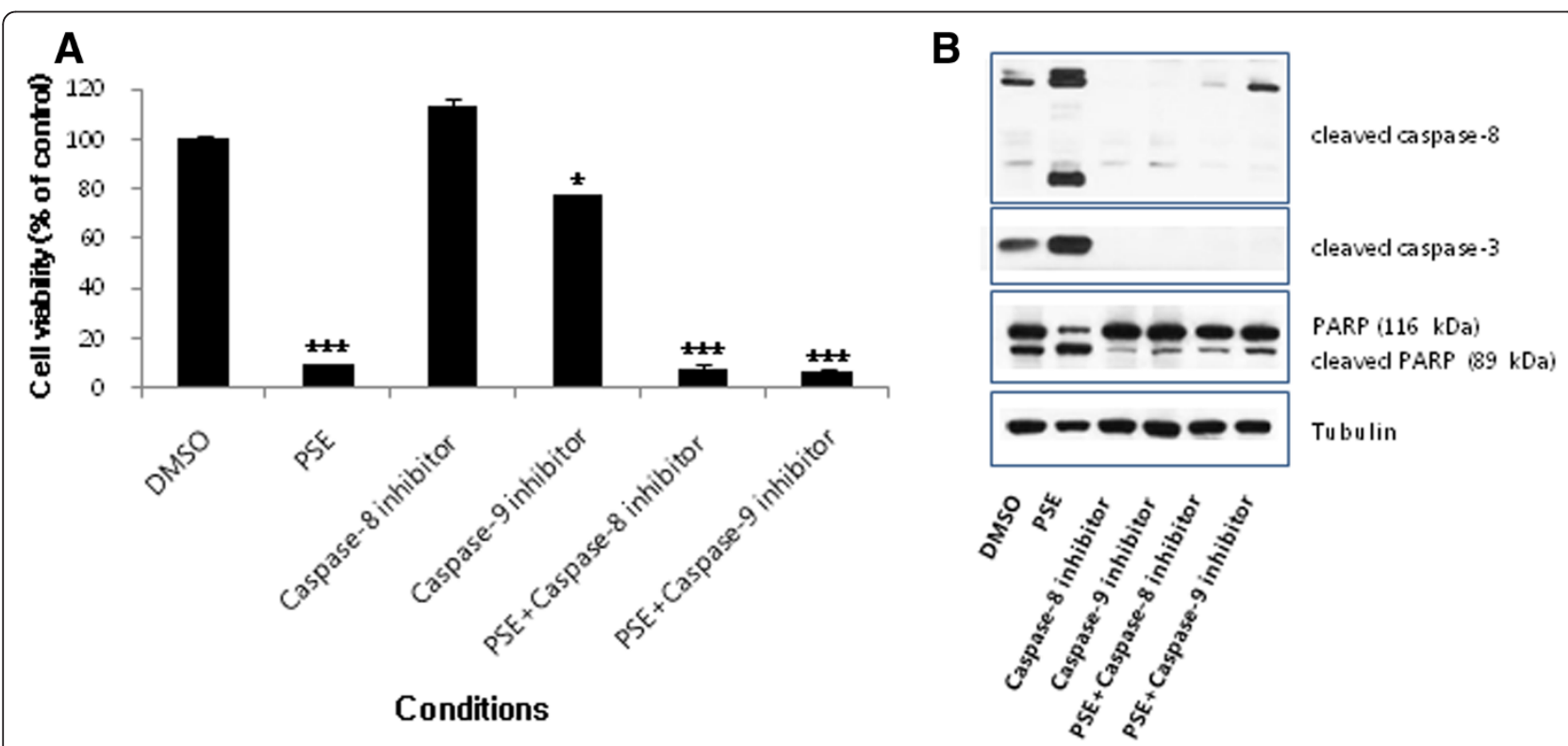

Figure 6 Effect of caspase- 8 inhibitor and caspase- 9 inhibitor on the apoptosis induced by PSE in AGS gastric cancer cells. (A) AGS Cells were seeded in 12-well culture plates at a density of $5 \times 10^{4}$ cells/well. The next day, cells were treated with caspase-8 inhibitor (40 $\square \mathrm{M}$ ) or caspase-9 inhibitor $(40 \square \mathrm{M})$ in the presence or absence of $200 \mathrm{\mu g} / \mathrm{ml}$ PSE for 3 days. Cells were harvested by trypsinization, resuspended in $1-$ $2 \mathrm{ml}$ of medium, and counted using a hemocytometer. Bars, SD. ${ }^{*} \mathrm{p}<0.05,{ }^{* * *} \mathrm{p}<0.001$. (B) AGS cells were exposed to $200 \mu \mathrm{g} / \mathrm{ml}$ PSE and $0.1 \%$ DMSO either with or without caspase-8 inhibitor (40 $\square \mathrm{M})$ and caspase-9 inhibitor (40 $\square \mathrm{M})$ for $24 \mathrm{~h}$, the cell lysates were separated by SDS-PAGE gel electrophoresis, and Western blotting with specific antibodies was performed (anti-cleaved caspase-8, anti-cleaved caspase-3, anti-cleavedPARP, and anti-Tubulin). The data shown are representative of three independent experiments that gave similar results. 


\section{Discussion}

Although the incidence of gastric cancer has declined worldwide, the death rate continues to rise in Eastern Asian countries $[25,26]$. In this study, we found that the PSE extract effectively inhibits gastric cancer cell growth via the extrinsic Fas-dependent apoptosis pathway.

Our results demonstrated that the PSE extract suppressed cell growth and induced AGS cell cytotoxicity in a dose- and time-dependent manner. The flow cytometry cell cycle analysis showed that the PSE extract increased the sub- $\mathrm{G}_{1}$ apoptotic fraction from $3.81 \%$ to $18.75 \%$.

In addition, morphological analysis demonstrated that there was a time-dependent increase in the $\mathrm{FSC}<150$ population from $2.47 \%(12 \mathrm{~h})$ to $13.42 \%(36 \mathrm{~h})$ after treatment with the PSE extract. In addition, the cells treated with either the PSE extract or cisplatin showed morphological changes in the cellular monolayer, including cell shrinkage and membrane blebs, as revealed by microscopic studies [27]. Cisplatin (cis-diamminedichloroplatinum(II)) is an anti-cancer agent that is currently used to treat patients with a wide variety of solid tumors, and it acts via a direct interaction with DNA to form DNA adducts [9,28-30]. Cisplatin is known to increase DNA fragmentation, so it was used as a positive control for our study. DNA fragmentation was observed in both the PSE extract - and cisplatin- treated AGS cells, confirming the induction of apoptosis.

Our western blot analyses suggest that the PSE extract induces apoptosis through the activation of the caspase cascade. The present study revealed that treatment with the PSE extract increased Fas receptor expression. Fas (FasL), a cell surface molecule that belongs to the tumor necrosis factor family, binds to its receptor Fas, which leads to apoptosis in Fas-bearing cells [31]. Up-regulated Fas receptor can lead to cleaved caspase-8, caspase-3,
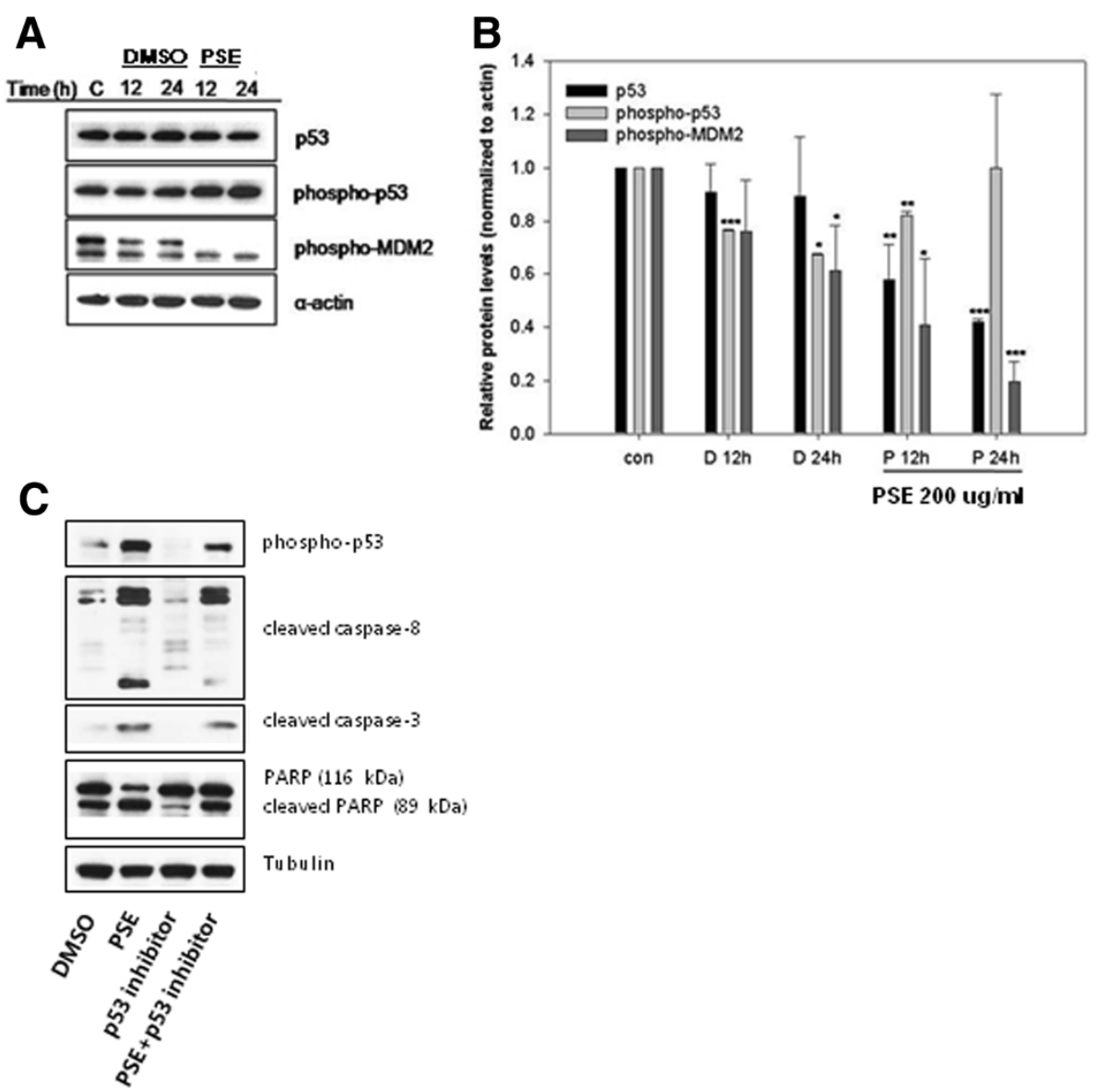

Figure 7 p53-dependent apoptosis is induced by PSE in AGS gastric cancer cells. (A) AGS cells were exposed to 200 $\mu \mathrm{g} / \mathrm{ml}$ PSE and $0.1 \%$ DMSO for $12 \mathrm{~h}$ and $24 \mathrm{~h}$. The cell lysates were separated by SDS-PAGE gel electrophoresis, and Western blotting with specific antibodies was performed (anti-p53, anti-phospho-p53, anti-phospho-MDM2, and anti-a-actin). (B) The band intensities were normalized to a-actin. Bars, SD. ${ }^{*} \mathrm{p}<0.05,{ }^{* *} \mathrm{p}<0.01,{ }^{* * *} \mathrm{p}<0.001$, control versus PSE-treated cells. (C) AGS cells were exposed to $200 \mathrm{\mu g} / \mathrm{ml}$ PSE and $0.1 \%$ DMSO for $24 \mathrm{~h}$ either with or without p53 inhibitor (Pifithrin-a, $20 \mu \mathrm{M}$ ). The cell lysates were separated by SDS-PAGE gel electrophoresis, and Western blotting with specific antibodies was performed (anti-phospho-p53, anti-cleaved caspase-8, anti-cleaved caspase-3, anti-cleaved-PARP, and anti-Tubulin). The data shown are representative of three independent experiments that gave similar results. 
and PARP. We observed such Fas-dependent apoptosis signaling in AGS cells treated with the PSE extract. To determine whether the apoptotic process was occurring in a caspase-dependent manner, we pre-treated AGS cells with $\mathrm{z}$-VED-fmk, which is a known pan-caspase inhibitor. We found that the growth inhibition induced by the PSE extract was abrogated by z-VAD-fmk, and the cleavages of caspase-8, caspase-3, and PARP were inhibited by $z$-VAD-fmk. Therefore, our data demonstrate that the apoptotic process induced by the PSE extract is caspase-dependent. Moreover, we found that caspase- 8 inhibitor or caspase-9 inhibitor alone did not strongly affect apoptosis in AGS cells. This event may explain that apoptosis needs the complex action of caspases and caspase does not work alone to affect apoptosis of cancer cells. They need complex mechanism to affect apoptosis. Therefore, caspase- 8 or caspase- 9 inhibitor alone did not strongly affect apoptosis of AGS gastric cancer cells. PSE seems to trigger complex cascade of caspases action to induce apoptosis. In contrast, the mitochondrial-dependent apoptosis pathway was not activated in AGS cells treated with the PSE extract. Overexpression of Bcl-2, an anti-apoptotic protein, prevents cells from initiating apoptosis, while increase of Bax, a pro-apoptotic protein, induces the intrinsic apoptosis pathway [32]. In the present study, we found that the levels of $\mathrm{Bax}$ and $\mathrm{Bcl}-2$ were not changed by the PSE extract. The ratio of $\mathrm{Bcl}-2 / \mathrm{Bax}$ was also unchanged. Furthermore, the PSE extract did not affect mitochondrial membrane potential (MMP), as shown by the maintenance of red fluorescence when the cells were dyed with JC-1. The mitochondrial membrane potential of intact cells could be measured by JC-1, a membrane potential sensitive dye [4]. When the MMP is stable, JC1 shows red fluorescence, due to the increase of $\mathrm{J}$ aggregate formation. With a loss of MMP, the formation of J-aggregates is reduced, leading to a change from red fluorescence to green fluorescence [30,33]. The lack of change in caspase-9, Bcl-2 and Bax expression that we observed is highly correlated with a stable MMP.

We also describe here that the PSE extract inhibited the proliferation of AGS cells in a p53- and MDM2dependent manner. After DNA damage, p53 is phosphorylated, which can restrict aberrant cell growth or induce apoptosis $[34,35]$. Phosphorylation of p53 leads to reduced phosphorylation of MDM2, the negative regulator of p53. MDM2 inactivation is known to be responsible for p53 stabilization (MDM2-p53 pathway) [36,37]. The p53 tumor suppressor inhibits cellular proliferation by inducing apoptosis in response to cellular stresses, including

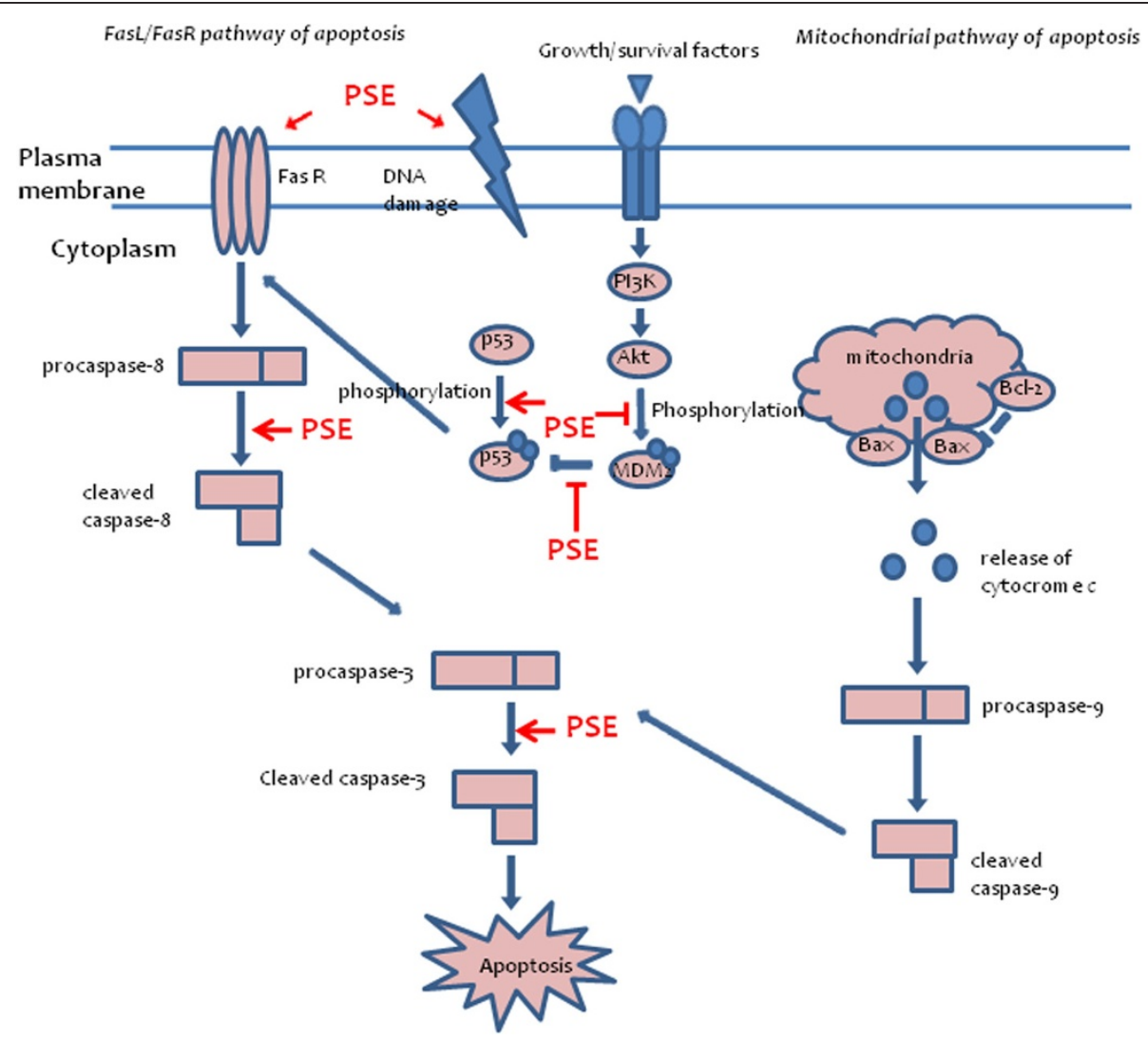

Figure 8 PSE induces p53-dependent and Fas-mediated apoptosis in AGS gastric cancer cells. 
DNA damage, growth factor deprivation, hypoxia, and oncogene activation [38,39]. p53-dependent apoptosis is induced by the caspase proteases and death receptors $[40,41]$ and functions through pro-apoptotic proteins including Bax, Noxa, or PUMA [37].

\section{Conclusions}

In conclusion, this study demonstrated that the PSE extract on AGS cells significantly inhibits cell proliferation and induces apoptotic cell death via the extrinsic Fasmediated apoptosis pathway (Figure 8). This induction of apoptosis also leads to the activation of caspases such as caspase-8, caspase- 3 , and cleavage of PARP. The p53MDM2 pathway also plays a role in the apoptotic cell death of AGS cells that is induced by the PSE extract. Our data clearly demonstrate that the PSE extract might be a potential anticancer agent for gastric cancer.

\section{Competing interests}

The authors declare that they have no competing interests related to this work.

\section{Authors' contributions}

HSC performed all of the experiments and wrote the manuscript. HSS corrected the English and helped draft the manuscript. JHK, JYU and YCS helped draft the manuscript. SGK critically revised the manuscript for intellectual content and gave final approval of the version to be published.

\section{Acknowledgements}

This work was supported partly by the Korea Science and Engineering Foundation (KOSEF) grant funded by the Korean government (MEST) (No. R13-2007-00000-0) and partly by a grant of the Traditional Korean Medicine R\&D Project, Ministry of Health \& Welfare, Republic of Korea (B110043). This research was also supported by Basic Science Research Program through the National Research Foundation of Korea(NRF) funded by the Ministry of Education, Science and Technology(2012R1A1A3004797). We thank Dr. Hwang-Phill Kim (Seoul National Cancer Institute) who provided the AGS cells for the study. We also acknowledge Soon Re Kim and Youn Kyung Choi (Laboratory of Clinical Biology and Pharmacogenomics, Department of Cancer Preventive Material Development, College of Oriental Medicine, Kyung Hee University) who greatly encouraged us to continue this study.

Received: 17 November 2011 Accepted: 30 August 2012

Published: 10 September 2012

\section{References}

1. Kuo PL, Hsu YL, Cho CY: Plumbagin induces G2-M arrest and autophagy by inhibiting the AKT/mammalian target of rapamycin pathway in breast cancer cells. Mol Cancer Ther 2006, 5:3209-3221.

2. Bhattacharya K, Samanta SK, Tripathi R, Mallick A, Chandra S, Pal BC, Shaha C, Mandal C: Apoptotic effects of mahanine on human leukemic cells are mediated through crosstalk between Apo-1/Fas signaling and the Bid protein and via mitochondrial pathways. Biochem Pharmacol 2010, 79:361-372.

3. Huang C, Ma WY, Goranson A, Dong Z: Resveratrol suppresses cell transformation and induces apoptosis through a p53-dependent pathway. Carcinogenesis 1999, 20:237-242.

4. Kim JH, Go HY, Jin DH, Kim HP, Hong MH, Chung WY, Park JH, Jang JB, Jung H, Shin YC, Kim SH, Ko SG: Inhibition of the PI3K-Akt/PKB survival pathway enhanced an ethanol extract of Rhus verniciflua Stokesinduced apoptosis via a mitochondrial pathway in AGS gastric cancer cell lines. Cancer Lett 2008, 265:197-205.

5. Tait SW, Green DR: Mitochondria and cell death: outer membrane permeabilization and beyond. Nat Rev Mol Cell Biol 2010, 11:621-632.
6. Kerr JF, Wyllie AH, Currie AR: Apoptosis: a basic biological phenomenon with wide-ranging implications in tissue kinetics. Br J Cancer 1972, 26:239-257.

7. Kim N: Butein sensitizes human leukemia cells to apoptosis induced by tumor necrosis factor-related apoptosis inducing ligand (TRAIL). Arch Pharm Res 2008, 31:1179-1186.

8. Alberts SR, Cervantes A, van de Velde CJ: Gastric cancer: epidemiology, pathology and treatment. Ann Oncol 2003, 14(Suppl 2):ii31-36.

9. Wu B, Zhang Q, Shen W, Zhu J: Anti-proliferative and chemosensitizing effects of luteolin on human gastric cancer AGS cell line. Mol Cell Biochem 2008, 313:125-132.

10. Inoue M, Tsugane S: Epidemiology of gastric cancer in Japan. Postgrad Med J 2005, 81:419-424.

11. Van Cutsem $\mathrm{E}$ : The treatment of advanced gastric cancer: new findings on the activity of the taxanes. Oncologist 2004, 9(Suppl 2):9-15.

12. Ajani JA: Evolving chemotherapy for advanced gastric cancer. Oncologist 2005, 10(Suppl 3):49-58.

13. Harikumar KB, Sung B, Pandey MK, Guha S, Krishnan S, Aggarwal BB: Escin, a pentacyclic triterpene, chemosensitizes human tumor cells through inhibition of nuclear factor-kappaB signaling pathway. Mol Pharmacol 2010, 77:818-827.

14. Hedberg I: Botanical methods in ethnopharmacology and the need for conservation of medicinal plants. J Ethnopharmacol 1993, 38:121-128.

15. Heinrich M, Gibbons S: Ethnopharmacology in drug discovery: an analysis of its role and potential contribution. J Pharm Pharmacol 2001, 53:425-432.

16. Arunasree KM: Anti-proliferative effects of carvacrol on a human metastatic breast cancer cell line, MDA-MB 231. Phytomedicine 2010, 17:581-588

17. Matsuda H, Li Y, Murakami T, Ninomiya K, Yamahara J, Yoshikawa M: Effects of escins la, Ib, Ila, and Ilb from horse chestnut, the seeds of Aesculus hippocastanum L., on acute inflammation in animals. Biol Pharm Bull 1997, 20:1092-1095.

18. Lau CH, Chan CM, Chan YW, Lau KM, Lau TW, Lam FC, Law WT, Che CT, Leung PC, Fung KP, Ho YY, Lau CB: Pharmacological investigations of the anti-diabetic effect of Cortex Moutan and its active component paeonol. Phytomedicine 2007, 14:778-784.

19. Hong MH, Kim JH, Na SH, Bae H, Shin YC, Kim SH, Ko SG: Inhibitory effects of Paeonia suffruticosa on allergic reactions by inhibiting the NFkappaB/I kappaB-alpha signaling pathway and phosphorylation of ERK in an animal model and human mast cells. Biosci Biotechnol Biochem 2010, 74:1152-1156.

20. Lee SJ, Lee IS, Mar W: Inhibition of inducible nitric oxide synthase and cyclooxygenase-2 activity by 1,2,3,4,6-penta-O-galloyl-beta-D-glucose in murine macrophage cells. Arch Pharm Res 2003, 26:832-839.

21. Ma YL, Bates S, Gurney AM: The effects of paeonol on the electrophysiological properties of cardiac ventricular myocytes. Eur J Pharmacol 2006, 545:87-92.

22. Chan BC, Hon KL, Leung PC, Sam SW, Fung KP, Lee MY, Lau HY: Traditional Chinese medicine for atopic eczema: PentaHerbs formula suppresses inflammatory mediators release from mast cells. J Ethnopharmacol 2008, 120:85-91.

23. Zhao GH, Shen YS, Ma JB, Li F, Shi XQ: Protection of polysaccharides- $2 b$ from mudan cortex of Paeonia suffruticosa andr on diabetic cataract in rats. Zhongguo Zhong Yao Za Zhi 2007, 32:2036-2039.

24. Nagasawa $H$, Iwabuchi T, Inatomi H: Protection by tree-peony (Paeonia suffruticosa Andr) of obesity in (SLN x C3H/He) F1 obese mice. In Vivo 1991, 5:115-118.

25. Pisani P, Parkin DM, Bray F, Ferlay J: Estimates of the worldwide mortality from 25 cancers in 1990. Int J Cancer 1999, 83:18-29.

26. Hu PJ, Yu J, Zeng ZR, Leung WK, Lin HL, Tang BD, Bai AH, Sung JJ: Chemoprevention of gastric cancer by celecoxib in rats. Gut 2004, 53:195-200.

27. Elmore S: Apoptosis: a review of programmed cell death. Toxicol Pathol 2007, 35:495-516.

28. Prestayko AW, D'Aoust JC, Issell BF, Crooke ST: Cisplatin (cis-diamminedichloroplatinum II). Cancer Treat Rev 1979, 6:17-39.

29. Kass GE, Eriksson JE, Weis M, Orrenius S, Chow SC: Chromatin condensation during apoptosis requires ATP. Biochem J 1996, 318(Pt 3):749-752. 
30. Mallick S, Ghosh P, Samanta SK, Kinra S, Pal BC, Gomes A, Vedasiromoni JR: Corchorusin-D, a saikosaponin-like compound isolated from Corchorus acutangulus Lam., targets mitochondrial apoptotic pathways in leukemic cell lines (HL-60 and U937). Cancer Chemother Pharmacol 2010, 66:709-719.

31. Nagata S, Golstein P: The Fas death factor. Science 1995, 267:1449-1456.

32. Yang J, Liu X, Bhalla K, Kim CN, Ibrado AM, Cai J, Peng TI, Jones DP, Wang X: Prevention of apoptosis by $\mathrm{BCl}-2$ : release of cytochrome $\mathrm{c}$ from mitochondria blocked. Science 1997, 275:1129-1132.

33. Smiley ST, Reers M, Mottola-Hartshorn C, Lin M, Chen A, Smith TW, Steele GD Jr, Chen LB: Intracellular heterogeneity in mitochondrial membrane potentials revealed by a J-aggregate-forming lipophilic cation JC-1. Proc Natl Acad Sci USA 1991, 88:3671-3675.

34. Giaccia AJ, Kastan MB: The complexity of p53 modulation: emerging patterns from divergent signals. Genes Dev 1998, 12:2973-2983.

35. Jin S, Levine AJ: The p53 functional circuit. J Cell Sci 2001, 114:4139-4140.

36. Shieh SY, Ikeda M, Taya Y, Prives C: DNA damage-induced phosphorylation of p53 alleviates inhibition by MDM2. Cell 1997, 91:325-334.

37. Ju JH, Jeon MJ, Yang W, Lee KM, Seo HS, Shin I: Induction of apoptotic cell death by Pharbitis nil extract in HER2-overexpressing MCF-7 cells. J Ethnopharmacol 2011, 133:126-31.

38. Schuler M, Green DR: Mechanisms of p53-dependent apoptosis. Biochem Soc Trans 2001, 29:684-688.

39. Shen Y, White E: P53-Dependent Apoptosis Pathways. Adv Cancer Res 2001, 82:55-84.

40. Haupt S, Berger M, Goldberg Z, Haupt Y: Apoptosis - the p53 network. J Cell Sci 2003, 116:4077-4085.

41. Gottlieb TM, Leal JF, Seger R, Taya Y, Oren M: Cross-talk between Akt, p53 and Mdm2: possible implications for the regulation of apoptosis. Oncogene 2002, 21:1299-1303.

doi:10.1186/1423-0127-19-82

Cite this article as: Choi et al:: Ethanol extract of paeonia suffruticosa Andrews (PSE) induced AGS human gastric cancer cell apoptosis via fasdependent apoptosis and MDM2-p53 pathways. Journal of Biomedical Science 2012 19:82.

\section{Submit your next manuscript to BioMed Central and take full advantage of:}

- Convenient online submission

- Thorough peer review

- No space constraints or color figure charges

- Immediate publication on acceptance

- Inclusion in PubMed, CAS, Scopus and Google Scholar

- Research which is freely available for redistribution 